\title{
O MITO DA CONSPIRAÇÁO JESUÍTICA NO SÉCULO XIX: DAS PÁGINAS DA IMPRENSA AO UNIVERSO HISTÓRICO DE AS MINAS DE PRATA, DE JOSÉ DE ALENCAR
}

\section{THE MYTH OF THE JESUIT CONSPIRACY IN THE XIX CENTURY: FROM THE PAGES OF THE PRESS TO THE HISTORICAL UNIVERSE OF AS MINAS DE PRATA (THE SILVER MINES), BY JOSÉ DE ALENCAR}

Resumo: $\mathrm{O}$ presente trabalho investiga a ressonância de propagandas e leituras antijesuíticas na ficção histórica de José de Alencar. As investigaçōes debruçam-se, em particular, sobre os debates e polêmicas em torno do libelo as Monita Secreta (Instruçôes Secretas dos Jesuitas) e dos folhetins franceses $O$ Judeu Errante, de Eugène Sue, e $O$ Visconde de Bragelonne, de Alexandre Dumas, que circulam na imprensa fluminense e contribuem para a configuraçáo de aspectos temáticos e ideológicos do romance As Minas de Prata, de Alencar.

Palavras-chave: mito jesuitico; leituras antijesuiticas; romance histórico; romance folhetim.

Abstract: This work investigates the resonance of advertisements and anti-Jesuitical readings in José de Alencar's historical fiction. The investigations focus in particular on the debates and polemics surrounding the libelo as Monita Secreta (Secret Instructions from the Jesuits) and the French novels The Wandering Jew, by Eugène Sue, and The Viscount de Bragelonne, by Alexandre Dumas, which circulate in the Rio de Janeiro press and contribute to the configuration of thematic and ideological aspects of the novel The Silver Mines, by Alencar.

Keywords: jesuit myth; anti-jesuitical readings; historical novel; roman-feuilleton.

\section{Introduçáo}

A partir das décadas de 1830 e de 1840 , as propagandas e romances

\footnotetext{
${ }^{1}$ Pós-doutoranda (PNPD/CAPES) do Programa de Pós-graduação em Letras da Universidade Estadual Paulista (UNESP)
} 
de temáticas antijesuíticas que circulam na imprensa fluminense, caso do libelo as Monita Secreta e dos folhetins franceses O Judeu Errante e $O$ Visconde de Bragelonne, suscitam conflitos e confrontos religiosos no âmbito das discussões políticas do país, cujas manifestaçóes ideológicas são reinterpretadas pelos romances e prosas ficcionais brasileiras desse período. Não ocasionalmente, os debates e controvérsias acerca da religiáo cristã vêm à tona no momento de reflexão sobre os elementos identitários da pátria, que animaram os letrados brasileiros daquele período. Em meio a esse contexto, a religiáo cristá seria responsável pretensamente por unir o povo em torno de suas doutrinas eclesiásticas e por instruir e moralizar a nação. Religiáo, povo e território resguardariam, assim, os traços que legitimariam a consolidação do Brasil, delineando-se como temas a serem debatidos na imprensa e no Instituto Histórico e Geográfico Brasileiro (IHGB), lugares que orbitam em torno da política Imperial e difundem os assuntos de relevo ao processo identitário.

Ao conferirem um espaço importante à Religião Católica, os homens de letras necessariamente precisariam rever a imagem da Companhia de Jesus, tendo em vista o papel que esta Ordem Religiosa assumiu no passado colonial e que poderia assumir no Brasil Império.

No Brasil, o processo da reinvenção dos jesuítas fomenta-se por reinterpretaçóes e sistematizações marcadas, por um lado, pela circulação e consolidação da literatura antijesuítica entre as décadas de 1830-1860 na imprensa fluminense e no IHGB, e, por outro, pela mitificação dos primeiros missionários no Brasil representada pelos mesmos espaços. Com efeito, o movimento de ataque aos jesuítas ganha maiores proporçôes, principalmente, após a década de 1840, e as acusaçôes, denúncias e queixas contra os inacianos marcariam um forte ritmo de contestação à Companhia de Jesus.

Interagindo com essa rede de interlocução, o romance histórico $A s$ Minas de Prata (1865), de José de Alencar, representa na sua estrutura romanesca o movimento de criaçáo da Companhia de Jesus, movimento que resgata o discurso controverso, exaltado e opositor que, desde o surgimento da Corporação, demarcou dissidências no próprio seio da esfera eclesiástica.

A construçáo das leituras antijesuíticas na prosa de Alencar toma como referência os aspectos conspiratórios da Companhia, explorados pelas narrativas francesas $O$ Judeu Errante e $O$ Visconde de Bragelonne,e, em particular, considera uma famosa propaganda antijesuítica, as Monita Secreta (Instruçôes Secretas dos Jesuitas), que também convalidou e consolidou 
a ideia da conspiração dos loiolanos. Assim, na obra alencariana, as imagens de uma sociedade oculta e de seu catecismo secreto parecem ser inspiradas a partir deste libelo, que é reformulado em distintos gêneros textuais ao decorrer de séculos.

Recuando três décadas antes da publicação de As Minas, a imprensa fluminense de 1830 começa a circular as Monita, propaganda importante para a consagração do "mito jesuíta". Nessa época, as discussóes se tornam propícias para a recepção de O Judeu Errante, ao mesmo tempo em que se colocam como leituras precursoras da formação de uma tradiçáo anticatólica.

O impacto dessa propaganda no Brasil se faz sentir na discussão sobre os jesuítas e sua forma de conceber a prática religiosa, que passa a ser revista. Entender o papel que as Monita Secreta tiveram na Europa se faz como um espaço entroncado pelas reescritas dos jesuítas, cujas rearticulações desafiam a visão da Companhia como elemento constituinte da civilidade no Brasil.

As Monita Secreta constituem um libelo difamório do século XVII, que ao cabo de 17 capítulos, testemunha as supostas estratégias manipulatórias da Companhia de Jesus. Dada a sua grande circulação internacional, teve forte influência para a consagração do anticlericalismo oitocentista e, a partir da década de 1830, divulga junto aos jornais do Brasil um conteúdo conspiratório acerca do "catecismo secreto" dos jesuítas, o que influiria sobre os projetos literários de folhetins oitocentistas dedicados a representação da nacionalidade e da religião no Brasil.

Nos anos de 1840, o romance antijesuítico O Judeu Errante (18441845), de Eugène Sue, torna-se objeto de discussóes e polêmicas no âmbito político e literário da imprensa do Rio de Janeiro, o que denota a ressonância da inclinação anticatólica, que tomara a França do século XIX. Sensível à leitura anticatólica de Sue, o folhetim O Visconde de Bragelonne (1847), de Alexandre Dumas, publicado anos depois, também se envereda pelo combate ao jesuitismo na França, circulando, em menor proporção, no Brasil.

Ao transportar para o folhetim os debates e controvérsias sobre a Ordem Inaciana, ambos os romances reacendem o movimento anticlerical e provocam reação por parte dos defensores dos eclesiásticos na França. Escritos sob Monarquia de Julho, os folhetins de Dumas e de Sue compreendem um contexto de conflitos embasados nas disputas entre a Universidade e o Colégio da Companhia de Jesus. As reflexôes sobre sociedade e religião suscitadas pelas obras fazem do folhetim uma poderosa arma de propaganda contra a Ordem Inaciana, haja vista que a popularidade que os folhetins 
alcançaram foi suficiente para a recomposição do mito jesuíta². O folhetim de Sue, de ampla circulação na imprensa brasileira, contribuiu para difundir entre nós as tensóes político-religiosas da França, influindo sobre o antijesuitísmo que se imprime em algumas obras literárias do período, tais como As Minas de prata, de José de Alencar. As críticas à Companhia efetuadas pelo romance de Alencar parecem ecoar, em alguma medida, aspectos da trama de O Judeu Errante e de O Visconde de Bragelonne, e a atmosfera conspiratória das Monita Secreta, de modo que sob o manto do chamado "mitodos jesuítas", entendido aqui, sobretudo, como produto da censura às atividades da Companhia, se estabelecem alguns dos modelos da ficção alencariana. Assim, as imagens de uma sociedade oculta e de seu catecismo secreto ganham espaço na trama histórica de As Minas de Prata, obra expressiva dentro do projeto nacionalista de José de Alencar que reconfigura o passado do país com olhos voltados para preocupaçóes de seus contemporâneos, em particular, para a polêmica em torno dos jesuítas.

Ora, as querelas religiosas da Companhia de Jesus são circunscritas como um problema histórico e identitário em As Minas, cuja narrativa apreende as formas ambivalentesdos movimentos da religião católica no Brasil Colonial. Na obra, a imagem de um país dominado por dogmas eclesiásticos configura, sob um viés, a ordem e os conceitos de progresso, que moldam as "feiçôes nacionais" e os princípios de nacionalidade unificadora. Por outro lado, se José de Alencar delineia o catolicismo como símbolo do processo civilizatório, ele também incorpora e ressignifica a decadência da igreja, provocada, principalmente, pelos jesuítas. Assim, os processos de nacionalização da Instituição Religiosa configuram diversificados conflitos na percepção de um passado coerente e unificado, e José de Alencar reabsorve as contradiçóes da esfera eclesiástica, encaminhando determinadas

\footnotetext{
${ }^{1}$ Consideramos aqui o mito negativo dos jesuítas. Os estudos de Michel Leroy sobre o mito jesuíta na França e os de Eduardo Franco em Portugal fornecem uma investigação aprofundada sobre o movimento do antijesuitismo nos respectivos países. Segundo Leroy, o mito jesuíta, em sua pesquisa, não tem a pretensão de se elevar à dignidade dos mitos mais antigos [...]. "É um mito negro, nutrido pelo pavor e pela execração, que cerca a figura do Inimigo" (LEROY, 1999. p. 14, grifo do autor). O estudo de Franco sobre a literatura antijesuítica tece a seguinte conceituação: "Este conjunto variegado de documentação constitui o universo heteróclito daquilo que designamos grosso modo de literatura antijesuítica, em geral, marcado psicologicamente pela fobia e socialmente pelo combate em todas as frentes contra um inimigo que se imagina estar em todo e em qualquer lado." (FRANCO, 2006, p. 310, grifos do autor). Ainda, nas investigaçóes sobre os loiolanos, Franco trabalha com a ideia de mimetismo, identificando a "lenda negra" da Companhia de Jesus como uma das características mais salientes do mito jesuíta, e como um fenômeno de longa duração, que, por se desdobrar num movimento repetitivo, desmascara o seu caráter mimético (FRANCO, 2007).
} 
representaçôes, cuja ambiguidade se realiza no aproveitamento do catolicismo em outras áreas e esferas. Logo, a prática do catolicismo não deixa de ser um obstáculo para a consolidação da pátria na referida prosa ficcional, visto o importante papel que é atribuído à religião enquanto instrumento ideológico que serve ao discurso da unificação identitária, ideia propagada principalmente pelo IHGB e reinterpretada pelo romance alencariano. Cabem, então, aos intelectuais responder às demandas de sua contemporaneidade.

Desse modo, o cotejo que propomos entre as propagandas, representaçóes e leituras antijesuíticas veiculadas pela imprensa fluminense oitocentista e as figuraçôes dos jesuítas em As Minas de Prata permite reconstituir os debates ideológicos que contribuem para que o romance histórico seja um gênero, por um lado, voltado para a investigação (e recriação) do passado e, por outro lado, fortemente ancorado no solo de sua época contemporânea.

\section{As Monita Secreta e as raízes do mito dos jesuítas: a conspiraçáo religio- sa estampada nos jornais nacionais e estrangeiros}

Em meados do século XIX, os jornais fluminenses repercutem imagens negativas da Companhia de Jesus por meio de discursos e representaçôes críticas, que circulam sob distintas rubricas jornalísticas: Exterior, Notícia do exterior, Cartas ao leitor, Publicaçôes a pedido, Folhetim. Tais textos ligam-se a uma crescente movimentação antijesuítica em vários países da Europa, movimentação essa que desponta como contrária à atuação da Instituição Religiosa, expondo críticas que se manifestam como ressonâncias de reservas que a Companhia de Jesus desperta desde o seu surgimento. Dessa maneira, o fenômeno do antijesuitismo nos oitocentos cresce proporcionalmente à disseminação e expansão do poder jesuítico apropriando-se de um discurso que recupera os elementos formadores do chamado mito da Corporação Religiosa, cujas imagens foram produzidas no cerne da literatura antijesuítica que se inscreveu em todos os cenários em que os loiolanos tiveram alguma ação.

O discurso contra os loiolanos tem suas raízes no nascimento controverso da Ordem, que emerge num quadro de renovação do modelo eclesiástico católico e de reestruturação religiosa. Vista a partir da atualização dos dogmas e doutrinas da Igreja Católica, a Instituiçáo surgiu num momento de declínio do catolicismo, o que exigia uma fase de revisóes, 
mudanças, e, sobretudo, reformas que combates sem o protestantismo emergente. A renovação do catolicismo contou com uma orientação mais prática, e a Companhia de Jesus equacionou-se nesse processo, defendendo os deveres religiosos e a espiritualidade náo como fins em si mesmos, mas como forças motoras de transformaçôes da sociedade, ideal que possibilitou a conversão em diversos territórios e sua expansão por diversos continentes. A Ordem formou-se num processo de relaxamento moral, de politização e de militarização, dentre outros fatores da organização religiosa e de sua concepção espiritual, que vão dinamizar as grandes controvérsias em torno de sua eficácia. Aliás, esses aspectos propiciaram a readaptação do modelo tradicional eclesiástico com a atualizaçáo do catolicismo que se desenvolveu na síntese da reforma eclesiástica e da cultura renascentista. A Companhia apreciava a valoração do indivíduo e do seu espírito crítico, e a capacitação do saber e de técnicas. Tais mudanças geraram contestaçóes que forneceram subsídios à amosfera conspiratória construída pelas Instruçôes Secretas dos jesuítas. "Este libelo é, pois, um reflexo do clima de descontentamento, das fraturas, das reformas e das transformaçóes que se tinham verificado no seio da Ordem dos Jesuítas" (FRANCO; VOGEL, 2002, p. 25). ${ }^{3}$ Por sua vez, o documento tornou-se uma poderosa arma contra a Companhia, marcando o nascimento do mito jesuítico. ${ }^{4}$

Desde sua primeira publicação nos seiscentos, o libelo difamatório ganhou reedições em latim e traduçóes em línguas vernáculas, como o francês, alemão, espanhol, inglês, italiano, tornando-se internacionalmente conhecido. Segundo Michel Leroy (1999), as Monita Secreta representam um poderoso testemunho da mentalidade conspiradora jesuítica. Para este crítico, o autor das Instruçóes revelaria as estratégias manipuladas pela Ordem para diversas finalidades, como adquirir bens, captar a confiança de poderoso, aumentar a riqueza da sociedade, conquistar viúvas ricas, afastar outras ordens. O ponto ápice da propaganda é a denúncia de que a sociedade dos jesuítas teria como maior doutrina a dominação do mundo, camuflada

\footnotetext{
2"Assim sendo, não pode ser desligado dessa conjuntura de dissídio, confrontação, reforma, e repressão de abusos e desvios, acontecida no generalato de Acquaviva, a apariçấo dos Monita secreta, precisamente da autoria de um membro banido da Companhia de Jesus. Logo, Este libelo é, pois, um reflexo do clima de descontentamento, das fraturas, das reformas e das transformaçóes que se tinham verificado no seio da Ordem dos Jesuítas. Essas Instruçôes, somente reservadas a um pequeno número de escolhidos de entre os superiores da Ordem, teriam por objetivos, na sua totalidade, promover o aumento do poder temporal e das riquezas da Companhia de Jesus através de meios poucos católicos." (FRANCO; VOGEL, 2002, p. 25; grifos nossos).
}

${ }^{3}$ A contextualização da Companhia está embasada nos estudados de Eduardo Franco. 
sob os pretextos religiosos de seus dogmas, e contaria com o apoio do papa.

Ora, a propaganda antijesuítica encontraria releituras favoráveis a sua circulação, servindo a um movimento internacional contra os clericais. No caso do século XIX, os aspectos do mito jesuíta, em particular, o traço conspiratório atende à demanda de questóes políticas da época, seja no Brasil Imperial, no qual a invasão dos jesuítas no sul demanda atenção quanto a sua concorrência com o poder temporal, seja na França da Monarquia de Julho, país cuja produção cultural circula fortemente no Brasil, e que traz um contexto no qual os jesuítas dominam universidades, o que desperta polêmicas quanto a sua atuação na arena educacional.

$\mathrm{Na}$ França de 1830, tal documento influencia a ficção que se debruça sobre a temática antijesuítica. De acordo com Leroy, o mito jesuíta na França ganhou eficácia máxima pelas sátiras de Béranger, e pelo romance folhetim de Eugène Sue, $O$ Judeu Errante, contudo, não ficou restrito à escrita ficcional. As ações de Rodin (jesuíta de O Judeu Errante) e Aramis (jesuíta de $O$ Visconde de Bragelonne) ganham maior densidade crítica, na medida em que respondem ao quadro político da França. Na década de 1830, período focalizado na obra $O$ Judeu Errante, a França passava por uma querela entre Igreja e Universidade, ou melhor, os poderes da Igreja concorriam com os da Universidade, tentando dominar a rede de ensino. Os professores franceses Quinet e Michelet entram na discussão contra os jesuítas. ${ }^{5}$ Ao lado desse ataque, a publicação dos romances-folhetins, como de $O$ Judeu Errante e $O$ Visconde de Bragelonne, amplifica o poder do mito jesuíta. Ao transportar para folhetim os debates e controvérsias sobre a Ordem Inaciana, sobretudo, O Judeu Errante reacende o movimento anticatólico e provoca reação por parte dos defensores dos eclesiásticos na França. As reflexóes sobre sociedade e religião suscitadas pela obra de Sue fazem da ficção uma poderosa arma de propaganda contra a Ordem inaciana e sua popularidade foi suficiente para a recomposição do mito jesuíta.

No Brasil, a circulação do contexto político francês, em consonância

${ }^{4}$ Leroy analisa o impacto do Judeu Errante no contexto francês, bem como as réplicas do Colégio da França: "O sucesso do JuifErrant foi prodigioso. Le Constituionnel que duplicou o seu formato e aumentou de doze para vinte o número das suas colunas, ganhou $20 \mathrm{mil}$ assinaturas - à volta de 200 mil leitores. Falsificaçóes, traduçôes, aparecem por todo o lado: em alemão, espanhol, holandês, português, Hebreu (em Varsóvia), persa, russo, checo" (LEROY, 1999, p. 97, grifos do autor); "as aulas de Michelet e Quinet consagradas aos Jesuítas, na Primavera de 1843, inserem-se na ofensiva lançada pelo universitários contra os adversários do monopólio. Substituídas e comentadas pela imprensa, seguidas por um público numeroso, as liçóes dos dois professores, no Colégio de França, vêm coroar a réplica universitária" (LEROY, 1999, p. 86). 
com a publicação dos referidos folhetins, propicia a propagação das Monita Secreta, cujo teor ideológico vincula-se ao contexto político local. Ou seja, se por um lado podemos pensar que os folhetins franceses ganham repercussão, também podemos interpretar que eles jogam luz sobre o libelo e que, por outro lado, também recebem novos olhares a partir do libelo.

No caso brasileiro, as Monita são reapropriadas em distintos contextos, além do fato de aparecer em anúncios do Diário do Rio de Janeiro, Correio da Tarde, Correio Mercantil, Diário Mercantil, Diário Fluminense, Correio Paulistano, com o nome de Monita secreta, ou Instruçóes Secretas dos Jesuitas; Monitoria secreta, ou Instruçóes Secretas dos Jesuitas; Monita Secreta dos Jesuitas.

$\mathrm{Na}$ década de 30, os jornais fluminenses propagam o título do libelo, contextualizado pela situação sócio-política brasileira. Ao manter seus significados, como o tom de mistério, conspiração, maquinação, deixa de se referir à sociedade dos jesuítas, adaptando-se à situação particular do Brasil naquele período. A transferência de significação a quadros políticos, que inspiram sigilo, complô, dissimulação, nos permite reconstituir a trajetória de readaptaçóes do termo e observar seu uso corrente, fatores que nos possibilitam interpretar que o vocábulo é empregado com certa recorrência e, provavelmente, conhecido por aqueles que frequentavam a esfera política. $\mathrm{Na}$ imprensa fluminense desse período, deparamo-nos com ele em distintas revistas e jornais.

$\mathrm{Na}$ década de 60, deparamo-nos com informaçóes mais específicas sobre as Monita Secreta, inclusive, com uma recepção no jornal do Correio da tarde, que publica uma notícia sobre a obra, apropriando-se da ideia de que a Companhia de Jesus trabalha em favor de si mesma, e não do bemestar social, almejando dominar o mundo e conspirando contra todos que se opor a ela:

Publicou-se em Paris um livro que tem por título Monita secreta Societatis Jesu (Instruçóes secretas da Companhia de Jesus).

A Opinion Nationale dando a notícia deste livro, considera os jesuítas como uma sociedade cujos membros têm rompido todos os laços de família e de pátria que os ligava aos outros homens, e cujos esforços tendem a um fim único e formidável: o seu domínio sobre todas as naçóes da terra por todos os meios possíveis.

[...]

Finalmente termina recomendando a sua leitura e citando para exemplo os seguintes capítulos:

O que deve ser recomendado aos pregadores e aos confessores dos grandes 
(IV) e Modo de ganhar as viúvas ricas (VI). (Correio da Tarde, 17/07/1861, n. 168; grifos nossos).

Notamos que as informações secretas da Instituição Religiosa também são redimensionadas para a situação contemporânea da Ordem no Brasil, o que é significativo para entendermos a reconstituição de um contexto antijesuítico que, gradativamente, se constrói no Império.

As adaptações e transferências de significados, associadas à própria recepção do libelo na imprensa fluminense, nos permitem levantar a hipótese de que, em primeiro lugar, a imagem de uma sociedade dos jesuítas circula fortemente, ainda que seja em anúncios de jornais, em segundo, a propaganda contra os inacianos gesta os aspectos do mito jesuíta, mesmo com a expressão independente, posto que seu teor pejorativo e negativo colabora na construçáo de uma literatura antijesuítica, no engendramento de notícias dos periódicos sobre os loiolanos. Ainda que não possamos afirmar que Alencar conhecia o libelo Monita Secreta, podemos afirmar que ele conheceu a palavra relacionada ao universo político ${ }^{6}$ e teve acesso às criticas desenvolvidas também pela propaganda, por meio dos romances folhetins de Dumas e Sue.

Assim, o posicionamento ideológico dos jornais e os debates pró e contra o governo, na luta político-partidária, expóem o esforço crítico da sociedade da época. Levantamos a problemática de que a expressão Monita Secreta, simbólica de uma literatura antijesuítica, encontrou um território de efervescência política e, sobretudo, de natureza cristã, de que precisava para deslizar nas malhas da imprensa. A tônica geral desse vocábulo, cuja instrumentação consagrará o mito negativo dos inacianos, no fim das contas, pode ser encontrada junto à recepção dos folhetins franceses e, sobretudo, na leitura de As Minas de Prata. A fim de estendermos a amplitude das leituras antijuísticas, reconstituiremos o horizonte da apreciação críticas das obras francesas, e, em seguida, passaremos a análise dos romances.

\section{As leituras de O Judeu Errante e de $O$ Visconde de Bragelonne nas pági- nas da imprensa periódica: as ressonâncias do anticlericalismo}

\footnotetext{
${ }^{5} \mathrm{O}$ próprio Alencar empregaria o vocábulo na Câmara dos Deputados, anos após a publicação do romance As Minas: "O segredo desta política é a monita secreta. Somos realmente um país afortunado! [...] não carecemos de fatigar-nos, temos quem nos governe e até quem trace um roteiro invariável de governo, que deve servir para 10 ou 11 meses!" (Diário do Rio de Janeiro, 09/08/1871, p. 1; grifos nossos).
} 
Antes mesmo da publicação de As Minas de Prata, o folhetim de Eugene Sue $O$ Judeu Errante teve uma enorme popularidade para os padróes da época, explicada possivelmente pelo fato de a obra ser antijesuítica, o que mobiliza discussóes entre os representantes clericais e seus opositores, alcançando, inclusive, o palco político.

O impacto do folhetim francês na avaliação do papel negativo da Companhia mobiliza interesses e objetivos divergentes. Reflexo disso é o fato de a narrativa de Sue ser tomada como referência temática para prestigiar ou desvalorizar outras obras que se se engajaram no combate à atuação da Companhia de Jesus.

Nesse sentido, sob o pseudônimo de "O Catholico Romano", um leitor critica a publicaçáo do folhetim do Jornal do Commercio "A Sobrinha do Conego", de J. J. Teixeria, e a visão negativa dos jesuítas representada por tal romance, que, para ele, junto com outros romances como $O J u d e u$ Errante, confundiria o leitor. Segundo essa crítica, muitos leitores não saberiam discernir ficção de realidade e acreditariam que a pintura dos loiolanos nessas mencionadas obras seriam verídicas.

\footnotetext{
Confessamos a nossa indignaçáa ao ver a maneira por que o folhetim do Jornal do Commercio tratava o clero representado na pessoa do irmão de Affonso. A hipocrisia, o horrível abuso da confiança, o esquecimento de todas as leis do decoro vem carregar as suas negras cores o quadro em que representa o primeiro papel um eclesiástico!!! Ignora o nobre romancista de que para muita gente a leitura do folhetim é mais do que a de um livro do dogma? Náo vê o perigo de tomar-se a ficção pela realidade? Muitas pessoas conhecemos nós que não tem outra noção dos jesuítas senão a que lhes deu o Judeu Errante, e estão inabaláveis em suas convicçôes como maometano nas doutrinas de seu falso profeta (Correio Mercantil, 05/12/1850).
}

Termina com um apelo ao romancista para que publique obras de cunho mais moralizante, e represente o clero como protagonista, como uma das formas de educar o povo. Sob esta ótica, o escritor reestabelece e reproduz as mesmas relaçôes feitas pelo IHGB entre jesuítas e educação moral e civilizatória na década de 40, de modo que podemos observar que esta visão não só impregna os intelectuais, mas também outras camadas da população, ultrapassando o âmbito dos letrados.

Em particular, o Padre Miguel do Sacramento Lopes Gama se destaca em meio à recepçáo crítica da obra de Sue, a partir de escritos, como Observaçôes críticas sobre o romance do senhor Eugène Sue: O Judeu Errante (1850), e coma escrita do opúsculo $O$ Mal considerável da maior parte dos 
romances (1852), que, após sua morte, é dividido em 13 artigos e lançado no Correio Mercantil (1859). As reflexôes do padre confluem para uma análise moralista do folhetim de Sue, tendo em vista sua formação sacerdotal que contribui para seus ataques contra objeçôes aos dogmas católicos. Por um lado, Gama concorda que Sue elogia o Evangelho, todavia, de outro, centraliza em suas críticas acusaçóes anticlericais ao folhetim, visto que, segundo o padre, era necessário mostrar a imoralidade de certos romances e novelas.

Já, em contraponto a esta depreciação, uma carta publicada no jornal buscar dar veracidade ao texto de Sue. "Um Novo Rennepont" (Diário do Rio de Janeiro, 30/06/1846, p. 2), é extraído da "Restauração da Carta", um texto que atesta a veracidade da obra o Judeu Errante mostrando um caso similar em Roma, onde os jesuítas tomam a herança de um mancebo de Bolonha, que, apresentando um estado frágil de saúde, foi influenciado pelos inacianos e deixou sua herança à Companhia de Jesus. A circulação dessa notícia não só legitima e consagra a formulação negativa do mito jesuítico, mas também concede uma certidão de verdade à ficcionalização de Sue, desfazendo a pecha de "obra inverossímil". Nesse ponto, podemos perceber que o romance suscita e fomenta seus próprios boatos, alimentando a imaginação de seus leitores. Outros deles estariam embasados no fato de ser encomendado pelo rei da França, o que seria colocado em xeque pelo periódico "Progresso" de Pernambuco", transcrito no Correio da Tarde:

\footnotetext{
Nós poderíamos igualmente deixar sem resposta a asserção de ter sido o Judeu Errante encomendado por el-reiLuis Felipe. Com efeito, não há ai uma só pessoa que ignore que, desde que os reis de França se emanciparam completamente da tutela dos Papas, o ultramontanismo há sido em suas máos um potente instrumento de despotismo; e na verdade S. M. Luis Filipe não é de sorte algum inimigo dos Jesuítas, como o provam as recentes perseguiçóes que sofreram M. M. Michelet e E. Quinet, por terem querido atacar a Companhia de Jesus, nos cursos que ambos professavam no Colégio de França.

A obra de Eugenio Sue foi inspirada pela reação liberal, contra as maquinaçóes desta Companhia para recobrar a sua antiga influência. E por outro lado, quem vende uma obra sua por quarenta contos de réis a um especulador que torna a vendê-la imediatamente por oitenta contos, não carece de se pôr à mercê de ninguém (Correio da Tarde, 22/01/1848, p. 3).
}

Essa notícia é relevante conforme apresenta aos leitores brasileiros o quadro de perseguição da França. A citação de Michelet e de Quinet e suas aulas contra a Companhia fornecem as diretrizes do ensino no Colégio 
que passava por sérias transformaçôes, dentre elas, a tentativa de expulsar os jesuítas do ensino.

As manifestações críticas que incidem sobre $O$ Judeu Errante, vêm à baila e denota o contexto conturbado da época, sensível à força dos impactos do folhetim enquanto uma arma poderosa e incômoda.

Por sua vez, O Visconde de Bragelonne (1847), de Alexandre Dumas ${ }^{7}$, possui um alcance menor quanto à natureza temática do antijesuitísmo. É traduzido no Brasil, no ano de 1848, em meio às discussôes sobre os jesuítas na imprensa e no IHGB, e num período próximo ao Judeu Errante. Ainda que representasse criticamente a Companhia de Jesus, sua estrutura de capa e espada talvez tenha silenciado as críticas brasileiras ao romance, diferentemente das polêmicas causadas pela obra de Eugène Sue.

O folhetim de Dumas dá continuidade à narrativa de aventuras de $O s$ três mosqueteiros exploradas no primeiro volume da trilogia ${ }^{8}$. Se nesta obra o autor francês opera com material histórico do reinado de Luis XIII e seus confrontos com o primeiro ministro Richelieu, no terceiro volume ele explora o reinado de Luis XIV, os conflitos políticos entre os intendentes Fouquet e Colbert, e as relações conflituosas entre França e Inglaterra. No primeiro romance, os mosqueteiros lutam juntos a favor do rei e contra as tramas de Richelieu, ao passo que, no terceiro, eles mantêm contatos diferentes, encontrando-se em campos e interesses políticos e pessoais distintos. ${ }^{9} \mathrm{Na}$ última versão, o personagem Aramis se torna um jesuíta poderoso, traçando estratégias e planos ardilosos para dar um golpe de Estado e tomar o trono de Luís XIV:

- Enlouquecestes! Não há outro homem que possa assentar-se no trono de França a não ser Luís XIV. Não vejo nenhum. [Fouquet]

[...]

${ }^{6}$ Em Como e porque sou romancista, José de Alencar afirma ler os romances de Alexandre Dumas e outros da literatura francesa, sentindo-se preparado para lidar com a "escola francesa". A estrutura folhetinesca das obras de Dumas, e de outras desse momento tiveram grande influência sobre a construção estética de As Minas de Prata.

${ }^{7} \mathrm{~A}$ trilogia circula em anúncios de alguns periódicos fluminenses, como nos jornais $O$ Correio Mercantil, Diário do Rio de Janeiro e Jornal do Commercio.

${ }^{8} \mathrm{~A}$ segunda obra, Vinte anos depois, narra o período de regência, após a morte de Luís XIII. O romance trabalha com o momento em que o cardeal Mazzarino assume o cargo de Primeiro Ministro e enfrenta um movimento popular e Parlamentar articulado por príncipes contra seu poder. O caráter de Mazzarino em $O$ Visconde de Bragelonne já é determinado pela obra anterior: se revela um personagem meticuloso, ambicioso e frio. 
- O meu rei, ou melhor, o vosso rei, será tudo o que é preciso que seja, ficai descansado.

$[\ldots]$

- Vejamos - disse ele -vejamos: falastes em derrubar soberanos e substituilos por outros. Deus me perdoe! Mas, se não estou louco, foi o que dissestes há pouco.

- Não estais louco, e foi realmente.

- Por que?

- Porque podemos falar em tronos derrubados e reis criados, quando estamos acima dos reis e dos tronos .... deste mundo.

- Sois, entáo, todo-poderoso? - bradou Fouquet.

- Eu vo-lo disse e repito-o - declarou Aramis com o olhar brilhante e os lábios trêmulos. (DUMAS, 1954. p. 99; grifos nossos)

Entretanto, esse lado do romance não é ressaltado, visto que a trilogia ganha repercussão por conta das grandes aventuras dos mosqueteiros.

$\mathrm{O}$ romance atual admite uma tal variedade de formas, que a enumeraçáo e classificação de todas não exigiria pequeno cuidado a quem a cometesse. Ao lado dos monumentos do grande poeta escocês, que bem pode dizer-se o inventor do gênero em que talvez Miguel de Cervantes com seu $D$. Quixote e as Novellas Exemplares lhe não prestasse pouca luz, [...]; finalmente, A. Dumas pai, que a trilogia dos Mosqueteiros, Vinte anos Depois e Visconde de Bragelonne, posto que desigual e decadente no desempenho, coloca em uma altura de que a crítica acintosa náo o derrubará facilmente, porque estas obras, assim como algumas peças com que ilustrou o teatro francês, prometem viver mais do que desejariam os censores, que lhe estranham como delito até a rapidez e a fecundidade! (Correio Mercantil, 09/09/1863, p. 2; grifos nossos).

Esse último texto também traz uma crítica à literatura de Dumas com relação à de outros autores, como Alfredo de Vigny, Balzac e Victor Hugo, entretanto, assinala sua popularidade que incomoda os censores. Comumente, $O$ Visconde de Bragelonne sempre aparece no filáo folhetinesco da trilogia de Os Mosqueteiros.

A apreciação crítica sobre os folhetins franceses, em particular, sobre a obra $O$ Judeu Errante, deixa entrever o dilema em torno dos jesuítas, ao tomar como ponto em comum a imagem dos inacianos como conspiradores e maquiavélicos, signos reincidentes desde a criaçáo da Companhia e apontados no romance da época e que fomentaria as dissidências em relação à figura histórica dos jesuítas. De qualquer forma, ainda que haja posturas 
contrapostas, há de se reconhecer que tanto as favoráveis ao romance, quanto as depreciadoras partem das imagens negativas levantadas da obra, seja para atacar a narrativa de Sue ou defendê-la, o que levaria a uma ampla circulação do mito negativo dos jesuítas.

\section{As Monita e os jesuítas conspiradores: Rodin, Aramis e Molina}

As reinterpretaçôes da sociedade dos jesuítas pela prosa ficcional desse período, ainda que separadas por décadas, constituem não só um olhar do passado, caso de Dumas e Alencar, mas uma crítica severa à atuação dos membros clericais do momento contemporâneos aos autores, o que já está atualizado na obra de Sue. Provavelmente, a trama anticlerical de $O$ Judeu Errante tenha influenciado as obras e folhetins posteriores, sobretudo, o folhetim dumasiano. Os romances, ao analisar a Companhia como um poder concorrente da sociedade, ressignifica a Instituição como ambígua, e contrareligiosa. Multifacetada, a Ordem é ficcionalizada no seu deslizamento pelos poderes e favores políticos, levantando suspeitas e questionamentos relativos a sua ação temporal.

O Judeu Errante narra a trama do jesuíta Rodin contra a família Rennepont, cujos membros possuem direito a uma herança milionário, e o inaciano, por sua vez, ambiciona obtê-la. A narrativa trava o embate entre um poderoso e maquiavélico religioso, o jesuíta Rodin, e um núcleo familiar, de forma que, no eixo estrutural do romance, se organizam dois planos: o ardiloso núcleo dos inacianos, de um lado, e os descendentes de Mario Rennepont, de outro. A figura do poder oculto da Companhia mobiliza uma teia de contatos disseminados por várias partes e continentes em busca de fama, dinheiro e poder. A metáfora do poder oculto trabalhado na narrativa critica uma Instituição que tem aumentado sua influência sem que seja percebida, deslizando-se pelos espaços religiosos e políticos. $\mathrm{O}$ folhetim tenta desmascarar os veículos com os quais a Ordem manipula outras pessoas, bem como os instrumentos com os quais ganham espaços sob o pretexto de pregar sua doutrina religiosa.

Em O Visconde de Bragelonne, a conspiração da Companhia de Jesus é sintetizada na ação do personagem Aramis, que faz um complô contra a realeza, tendo em vista que almeja substituir Luís XIV por seu irmão gêmeo, o que lhe proporcionaria grandes vantagens na Companhia. No capítulo "O Segredo de Estado" do folhetim dumasiano, as entrevistas feitas pelo Geral a fim de selecionar o candidato ideal a substituí-lo deixam transparecer 
a extrema importância da Companhia, ao obter informações sigilosas de diferentes ordens e naturezas ${ }^{10}$. Se os candidatos que ofereceram tais informaçôes são vistos como espiôes e esbirros, e não como loiolanos aptos a exercerem a funçáo de Geral, por outro lado, eles prenunciam a faceta perigosa da Corporaçáo, uma vez que conseguem penetrar nos mais sigilosos segredos, inclusive, ter acesso ao projeto pontifício. O poder invencível e oculto da Instituição Eclesiástica plasma pela narrativa seja nas referências dos seus inimigos, no fluxo de dinheiro que circula e passa pelas mãos do $\mathrm{Sr}$. d'Herblay, também conhecido como Aramis, na proteção que a Instituição demonstra por determinados personagens.

A sociedade secreta da Ordem confere a Aramis privilégios que soube aproveitar e, dentre eles, consegue ser um dos confessores de detentos, cujas confissóes são de extrema importância, pois os presos da bastilha poderiam lhe relatar profundos segredos. Não é por acaso que a Ordem se coloca numa sociedade com o governador da Bastilha. Vale lembrar que o Geral procurava um substituto que lhe fornecesse um segredo de Estado, o que poderia ser facilmente encontrado com presos. Penetrando nesse espaço, Sr. d'Herblay tem acesso à cela onde se encontra o irmão de Luís XIV: "O exame que o prisioneiro acaba de fazer e que lhe revelava o caráter frio, astuto e dominador, impresso na fisionomia do Bispo de Vannes, era sem dúvida, pouco tranquilizador na situação do jovem [...]” (DUMAS, 1954, 1494).

A traição de grandes segredos por partes daqueles que concorriam ao cargo de Geral já sinaliza o almejado poder pela Ordem. O romance dumasiano não deixa de evidenciar a força dessa empresa que não se movimenta pelo lado espiritual. Diferentemente de Sue e, posteriormente da adaptação de Alencar, que apresentam pelo menos um jesuíta mergulhado na sua verdadeira missão, Dumas aprofunda e explora o lado pérfido e maquiavélico da Companhia, já desvelado nos critérios de seleção do Geral: aquele que apresentar um segredo de Estado.

Em As Minas de Prata, a trama recorre a situaçóes nas quais a Companhia entra em conflito com o poder governamental e com doutrinas dissidentes entre si. No cerne deste conflito, a oposição do personagem jesuíta Inácio Louriçal ao relaxamento moral e à adaptação anti-dogmática

${ }^{9} \mathrm{O}$ Geral recebe durante a entrevista quatro candidatados de distintas regiōes: o primeiro é da Alemanha e propóe fazer uma revolução europeia; o segundo candidato é espanhol e revela saber do plano de ataque de Luís XIV contra os espanhóis, caso se rompa a aliança entre Espanha e França; o terceiro é veneziano e denuncia projeto do papa, e, por último, Aramis, que por suposição, conta o segredo da rainha. 
exercidos pelo seu companheiro Molina suscita inquietaçáo e suspeitas quanto aos aspectos da politização da Ordem. Os planos inescrupulosos de Molina fazem jus a sua batina, não escolhida por vocação, mas sim pelo poder e reconhecimento que o traje preto lhe proporcionaria, e ele somente se interessa pela colônia brasileira pelo simples fato de buscar as minas de prata. A partir do momento em que se encontra no Brasil, sua atuação gravita em torno de várias empreitadas e alianças que mobiliza, chegando a corromper os padres de sua Ordem e a manobrar as doutrinas da Instituição religiosa. Molina maneja uma conspiraçáo contra o governador D. Francisco de Sousa, com o objetivo de obter o roteiro das minas, por outro.

A representação de Molina ${ }^{11}$ reapropria o discurso crítico construído pelos deslizes dos representantes da Companhia que corrompem as doutrinas religiosas. A reinvenção desse inaciano assemelha-se ao arquétipo do jesuíta Rodin, de Eugène Sue, pois o padre de origem espanhola, Molina, reúne inúmeras características do chamado "mito jesuítico". Molina antecipa os traços imorais e políticos que o leitor encontrará em personagens religiosos de outras obras de José de Alencar, como no padre de Guerra dos Mascates e nos loiolanos de Alfarrábios, bem como comporta as qualidades pouco escrupulosas de Samuel, de O Jesuita.

A influência da Ordem plasma suas forças invisíveis sob ângulos de vista distintos e sob diferentes planos, alcançando domínios particulares. Assim, se em As Minas de Prata, ela concorre com o poder governamental, na França seiscentista, ela quer tomar o poder de Luís XIV, e na França oitocentista, ela quer exterminar uma família de protestantes. As releituras da Instituição num mesmo período, os seiscentos, mesmo que seja em contextos específicos, propóe um elemento em comum: a concorrência dos eclesiásticos com poder temporal, seja com Filipe II, seja com Luís XIV.

Nas narrativas de José de Alencar, Eugène Sue e Alexandre Dumas,

\footnotetext{
10“[...] o padre Molina, expressão a mais elevada e singela do janota do século XVIII, é superior ao Rodin de Eugenio Sue, e digno êmulo do P.Ventura, de Rebello da Silva" (GARNIER, B. L. Catálogos dos livros de que é editor. V. 257, n. 2). Na breve descriçâo de As minas de Prata, no catálogo Garnier, o padre Molina aparece como uma figura elevada, superior ao personagem Rodin, de O Judeu Errante, de Sue, e digno do P. Ventura (aparece no romance A mocidade de D. João VI, de Rebello Silva). A leitura do catálogo permite registrar as leituras contemporâneas a obra de Alencar e seus possíveis alcances e diálogos, uma vez que forneceria ao leitor as primeiras impressóes do romance. Tendo isso em vista, apesar de Molina ser comparado a Rodin, ele não é descrito com características que o desqualificam, de modo que pudesse desfavorecer o interesse do leitor pelo livro. Apesar de o texto apreciar o personagem de Molina, podemos observar a importância desse personagem, ao figurar dentre a seleção de outros descritos pelo catálogo, como Estácio, Vaz de Caminha e D. Diogo Menezes.
} 
o complô é maquinado por integrantes da Ordem e se consome de formas diferentes; as três prosas representam de modos e procedimentos particulares a ameaça dos jesuítas ao Estado. Rodin tenta alcançar uma fortuna com a qual manejaria o papado e galgaria degraus do poder, Aramis tenta dar um golpe de Estado, e Molina tenta reaver a gruta das minas de prata antes de D. Francisco de Sousa.

A atmosfera conspiratória ecoa os motivos do complô de as Monita e reescreve os elementos do mito dos jesuítas, que já transitam nas páginas dos jornais.

Em As Minas de Prata, por exemplo, José de Alencar reinterpreta a filosofia de vida e o pensamento político da Ordem, sob os influxos da circulação da propaganda difamatória e da instrumentalização dos "códigos secretos”, que conferem corpo aos questionamentos político-ideológicos às concepçóes de Cláudio Acquaviva, na tentativa de apreender as nuances do poder atemporal junto à administração da Companhia na colônia.

Sendo assim, o escritor atribui aos personagens inacianos traços assemelhados às representaçóes anticlericais de As Monita Secreta, debruçandose sobre as críticas que dão moldura ao mito negativo da Companhia. $\mathrm{Na}$ obra ficcional de Alencar, a narrativa tematiza o espaço ambíguo dessa Ordem nos seiscentos, ora enquanto Instituição responsável por registrar o rico manancial do Novo Mundo, ora enquanto Instituição atuante no âmbito espiritual, dogmático e educacional no espaço da Bahia. Sob essas orientações, as anotações dos padres daquela época não só priorizavam as descriçôes da terra a ser explorada, mas também funcionavam como um registro de possíveis fundos monetários para a Companhia. Por sua vez, a missão da Companhia de Jesus é multifacetária, ramificando-se na catequese dos índios, no ensino religioso, na pregação aos fiéis, e, ambiguamente, no levantamento de fundos.

Em terras portuguesas ou francesas, as açôes politizadas dos jesuítas aproximam-se de alguns tópicos que se encontram nas informaçôes do libelo as Monita e formam a atmosfera conspiratória das instruçóes secretas, a saber: "De que maneira os Padres da Companhia poderão adquirir e conservar a familiaridade dos príncipes dos grandes e das pessoas"; "O que se deve recomendar aos pregadores e aos confessores dos grandes"; "Da maneira como se deve proceder para com os outros religiosos que desempenham na igreja as mesmas funçôes que nós"; "De que modo a Companhia poderá conquistar o afeto das viúvas ricas", "Como aumentar os rendimentos dos Colégios"; "Como se hão de escolher os jovens a admitir na Companhia, e 
como os conservar"; "Dos meios de fazer prosperar a Companhia"12.

Compartilhando teorias e práticas comuns a essas instruçóes, o padre Gusmão de Molina parece, grosso modo, reproduzi-las no ambiente da Bahia seiscentista diante das possibilidades daquele momento. $\mathrm{O}$ jesuíta marca reunióes com outros religiosos para distribuir funçóes e tarefas, de acordo com uma prática menos dogmática; interessa-se pelos confessores de pessoas que poderiam lhe auxiliar e poderiam aumentar as rendas da Ordem; prega um sermão direcionado ao governador D. Diogo de Menezes. Ao lado de Molina, o Colégio dos Jesuítas explora os bens da viúva D. Luíza de Paiva e mantém o protagonista Estácio sob seus cuidados, por conta de seu pai ser o descobridor das minas de prata.

Nas três obras, a Corporação dos inacianos desliza por entre espaços públicos e privados, e, por isso, ela se torna mais difícil de ser desmantelada e desmascarada. Rodin, Aramis, Molina se revestem de duplo poder: se conseguissem êxito, promoveriam náo só a si mesmos, mas também a Companhia. A Instituição fornece aos três poderes, com os quais poderiam alcançar status e fama.

Molina possui amplo poder devido a sua aliança com Cláudio Acquaviva, Rodin possui um alcance internacional, metaforizando o complô mundial da Companhia, e em O Visconde de Bragelonne, o nome "sociedade secreta" da Ordem confere a Aramis privilégios que soube aproveitar e, dentre eles, consegue ser um dos confessores de detentos, cujas confissóes são de extrema importância, pois os presos da bastilha poderiam lhe relatar profundos segredos.

Entretanto, a despeito desse amplo poder conferido aos jesuítas, os três personagens palmilham um caminho de derrocada rumo aos desfechos trágicos das obras: a morte de Rodin, o exílio de Aramis e o retorno de Molina ao sertão. Tais representaçóes poderiam figurar como possíveis respostas ao contexto de produção das obras, a saber, a necessidade de desmantelamento e expulsão da Companhia e do registro de sua memória.

Por sua vez, Alencar tenta recuperar seu personagem que passa por um processo de resignaçáa, retirando-se ao sertáo. Entretanto, o romance silencia quanto à atuação dos jesuítas posteriormente ao retiro de Molina para o sertão, o que suspende a trajetória da Companhia na obra e os possíveis caminhos pelos quais ela tomaria no Brasil Colonial, e, por sua vez, na contemporaneidade.

${ }^{11}$ Extraímos essas citações do livro de Franco e Vogel (2002). 
Seguindo as trilhas da construção do personagem jesuíta Rodin e Aramis, é possível entender melhor, no movimento da história da França, como Dumas e Sue conferem sentido a algumas questôes consideradas definidoras quanto à atuaçấo da Companhia de Jesus, cuja releitura pelo romance-folhetim joga luz ao poder da ficçáo no rodapé dos periódicos. $\mathrm{O}$ significado histórico das imagens é construído para os personagens inacianos nas referidas obras a partir da literatura antijesuítica e da construçāo do mito jesuítico na França, e recebem releituras e reapropriaçóes no Brasil. Para compreendê-las nos termos da época, analisamos não somente a trama dos romances, mas também a situação particular de cada país, da França e do Brasil, reconstituída pelos debates na imprensa fluminense, espaço no qual compreendemos as trocas culturais da dialética nacional-internacional.

\section{Consideraçóes finais}

O romance histórico de José de Alencar absorve os paradigmas construídos sobre as propagandas antijesuíticas, dadas a ler na porosidade das páginas da imprensa. O folhetim de Eugène Sue $e$ as polêmicas que acalentam os periódicos fornecem, em parte, o quadro de querelas e a produção de sentidos sobre os jesuítas. Nosso recorte tentou delimitar as leituras sobre a Companhia, conforme as especificidades e as características do público leitor. Nesse sentido, a obra alencariana responde ao seu tempo, ficcionalizando os debates da imprensa, alicerçando um movimento de contestaçáo à Companhia e descrevendo os aspectos decadentes dessa Instituição, que chega ao ponto máximo com a expulsão dos jesuítas. Podemos entender que a atualizaçáo que a Companhia obteve no seio da Igreja Católica não representa a Ordem que deve permanecer no Brasil. Não é por acaso que Rodin morre na trama de Sue, e que Molina se retira ao sertão, sem alcançarem seus objetivos, o que nos permite pensar que ambas as obras sugerem reformas na Companhia, ou mesmo, sua destruição.

\section{Referências}

ALENCAR, José de. Obra completa. Rio de Janeiro: Aguilar, 1958.

CHARTIER, Roger. A história cultural: entre práticas e representações. Lisboa: Difel, 1990.

CHARTIER, Roger. O mundo como representação. Estudos Avançados, v. 
5, n. 11, p. 173-191, 1991.

DOMINGOS, Simone Tiago. Política e memória: a polêmica sobre os jesuítas na Revista do IHGB e a política imperial (1839-1886). Dissertação (Mestrado na área de História). Universidade Estadual de Campinas, Campinas, 2009.

DUMAS, Alexandre. O Visconde de Bragelonne. Trad. Octávio Mendes Cajado. São Paulo: Saraiva, 1954.

FRANCO, José Eduardo. Fundação pombalina do mito da Companhia de Jesus. Revista de História das Ideias, v. 22, p. 122-125, 2001.

FRANCO, José Eduardo. O mito dos Jesuítas em Portugal: séculos XVI-XX. Revista Lusófona de Ciência das Religióes, n. 9/10, p. 303-314, 2006.

FRANCO, José Eduardo. O mito dos jesuítas: em Portugal, no Brasil, e no Oriente. Lisboa: Gradiva, 2007.

FRANCO, Eduardo José; VOGEL, Christine. Monita Secreta. Instruçóes secretas dos Jesuítas. História dum manual conspiracionista. Lisboa: Roma Editora, 2002.

LEROY, Michel. O Mito Jesuíta.De Béranger a Michelet. Trad. José Eduardo Franco. Lisboa: Roma Editora, 1999.

SUE, Eugène. O Judeu Errante. São Paulo: Brasil Editora, 1963.

VITORINO, Arthur José Renda. Leitores e leituras de romances franceses em nossas plagas imperiais. Cad. AEL, v.9, n.16/17, p. 58-92, 2002.

\section{Fontes Primárias}

Correio Mercantil

Diário do Rio de Janeiro

Correio da Tarde 